\title{
2. Engaging Citizens: Can Westminster coexist with meaningful citizen-centric engagement?
}

\author{
Gerry Stoker
}

In this chapter I want to explore six topics. First, to recognise that with much of the discussion concerning 'putting citizens first' and embracing more meaningful forms of democracy, there is an inherent normative and developmental dimension. For me, the topic of citizen engagement is framed in the context of a significant scale of 'anti-politics' in the popular culture of many countries. Turning to solutions to this issue, I next argue the need to recognise that there is no such thing as an 'average citizen', and that we need to develop audits and tools that are capable of embracing the full diversity of communities. I will argue, furthermore, that because of the necessity of blending different factors, designing the right solution is likely to be a matter of judgment. Finally, I end with a plea to take democracy seriously.

\section{Competing definitions of democracy}

First, to deal with the notion of democracy. There are many ways to characterise the different models of democracy, but a broad distinction that David Held has put forward in his book Models of Democracy (1987) is between those that offer a protective framing of the issues of democracy and those that offer a developmental framing.

The protective model of democracy can be explained simply as a competition between elected leaders involving organised group engagement; and that understanding of democracy is, in part, built out of a fear of the problems associated with over-engaging with citizens. According to this definition, traditionally, it was necessary to construct a form of democracy that, in effect, held back mass citizen engagement, but gave people enough engagement and enough participation to feel that they were able to influence the system. The goals of this form of democracy were to protect liberties (both of property and of human rights), and to construct stable government. 
Developmental framing is the other traditional way of characterising democracy. It expresses democracy as a fundamental human right; that individuals have the right to have a say over the things that affect them. Citizen engagement is central to this understanding of democracy because, so the argument goes, it builds better human beings and a better society. The goals of this second model are to create legitimate and effective outcomes, but stemming from shared learning and exchange of interests and ideas. Through sharing their understanding of problems and potential solutions, the fullest expression of citizenship in such a democracy is realised.

As these are two fundamentally different models, one should not assume that the arguments made in this volume of essays are normative-free. This is a normative-influenced zone and in effect, one can see the tension immediately in the title of my contribution, because Westminster and the Westminster model of governance is more in tune with the protective model of democracy than citizen-centric engagement, which is more compatible, by contrast, to the developmental model of democracy.

So, central to the themes discussed in this volume is a fundamental shift, as it were, from one understanding of democracy to another. For this reason these issues are often difficult to resolve because, in effect, much of what we as practitioners in and scholars of this field have been trying to do over the last two or three decades is graft the developmental model of democracy on to a protective model of democracy. This has resulted in a degree of confusion and tension.

These tensions, then, find expression in the debate concerning the prioritisation of representative forms of democracy in favour of direct or participative forms of democracy; whether we recognise the impact and importance of the development of critical and challenging citizens.

When it comes to the topic of citizen engagement with government, if we compare the 1950s with the present, there is evidence in nearly all Organisation for Economic Co-operation and Development (OECD) countries of a rise in the number of critical and challenging citizens, and that more citizens are interested in politics than they were four or five decades ago.

Furthermore, over this period, citizens' engagement and their involvement in politics has become less formal. It is conducted less through conventional institutions (for example, political parties) than through involvement in 'single issue' politics and, more generally, through civil society, social media and the Internet. At the same time, however, politics itself has become more centralised. There is now a focus on leaders instead of their parties, a trend that has come to define the modern political era. Running concurrent to this are constitutional 
trends, which have encouraged pluralism and devolution. There is also an increasing focus on the professionalisation of politics, meaning many politicians do not have any other professional experience to draw upon from their working life. And yet, there is a growing call in many countries for political systems to better reflect the diversity of the societies they represent.

These changes have come amidst the backdrop of the modern 24-hour news cycle with its emphasis on 'sound byte democracy' and the rise of civic journalism's use of the Internet as a way of projecting alternative news arguments and news agendas. Having briefly mentioned some of these political developments of the past 50 years, it is clear that the era has been one of contradictions and challenges.

\section{Democracy and the changing face of citizen- government engagement}

So, how are these two models of democracy responding to these trends? As far as the Westminster model is concerned, there is a degree of nervousness about increasing citizen engagement. This is because, from a protective perspective, it would be understandable to be cautious and concerned about how far citizens can push the state. Undoubtedly the Westminster model is feeling the pressure from increased citizen engagement, reflected in the increasing demands and challenges that originate with the citizens themselves.

Turning to the developmental model, there are some positive and reformminded trends that should be discussed. There are also some positive examples of change, but there is also the spectre of utopianism: designing forms of participation and engagement that are not compatible with the way people actually live their lives.

In terms of being equipped to function within the contemporary milieu of a stubborn anti-politics, both democratic models need to go through a period of rethinking. There is currently a lack of trust in key political institutions. Consider the latest findings of the Eurobarometer, an annual survey undertaken by the European Union (EU), which takes in the 27 countries of the EU. Taking those who trust from those who do not trust national governments, across the EU the figure is -35 per cent for governments (a significant negative finding); concerning each member state's parliaments it is -31 per cent.

When we look at the findings of the World Value Survey Association (Table 1), the picture is equally bleak. Respondents were asked how they rated democracy against their satisfaction with the way democracy is practiced in their respective 
countries. As Table 1 illustrates, their responses prove that across the world there is a gap between the perceived relative importance of democracy and the satisfaction with the performance of that democracy. The fact that some of the greatest dissatisfaction was expressed in North America and Western Europe reflects, one assumes, both the higher levels of expectation surrounding, and the importance placed on, democracy in those countries, but, equally, the sense that it is not fully delivering what it promises.

Table 1: Evidence of democratic deficit: Rating of importance of democracy against satisfaction with performance (out of 10)

\begin{tabular}{|l|l|}
\hline Scandinavia & Net -1.53 \\
\hline Asia-Pacific & Net -1.55 \\
\hline South America & Net -1.78 \\
\hline Africa & Net -1.91 \\
\hline North America & Net -2.20 \\
\hline Western Europe & Net -2.25 \\
\hline Middle East & Net -2.96 \\
\hline Central and Eastern Europe & Net -2.96 \\
\hline
\end{tabular}

Source: Pippa Norris and World Values Survey, 2005-2007; the democratic deficit is arrived at by calculating by the mean difference between the importance placed in the 'value of democracy' versus the assessment of how democratically the country was actually being governed at present. All of these regional clusters are negative indicating a deficit of actual performance.

Without discounting the variation in these figures, they suggest a general trend towards an established disengagement with politics. But really, it could be argued that this is nothing new - it's been a core feature of the way in which people have been thinking about democracy for three or four decades now. It is thus not a product of an immediate set of factors, rather, this mentality is ingrained in the way people think about democracy, and in many ways I think it reflects a wider feature of democracy: that democracy, as a collective form of decision-making, inevitably disappoints. This is because of the nature of the democratic promise, which gives citizens the right to engage on issues, but not the right to decide them.

The nature of the political process, which advantages compromise over truth, probably also explains this high level of civic cynicism. It can be argued that politics and politicians' behaviour contribute to the belief that democracy is somehow flawed.

In addition, there are three other factors that help explain the trend. One is the role of the media, particularly the way in which it frames politics and political choice, often in a simplistical and negative manner. Another is the breaking down of the control and influence that political parties have had over partisanship and 
the way in which people think about issues. Although this factor is perhaps less developed in Australia than in other liberal democracies, it is a feature of the Australian system. This also reflects the imbalance between performance delivery and expectations, in that citizens expect more from government itself, even though its diversity of interests and engagements stretch its capacity to deliver. An example can be seen in the efforts of UK Prime Minister David Cameron to appeal to citizens through his so-called 'happiness agenda.' The idea that happiness should be a metric against which governments measure their performance is stretching towards insanity.

While the idea of measuring a country's wealth other than through simple measures of gross domestic product is an important one, the presentation of the 'happiness agenda' is spectacularly silly. I am not sure, either, that governments are necessarily equipped to lead the discussion on this issue, because of the risk that, just because a government is talking about something, it is assumed they are taking responsibility for it.

\section{There's no such thing as an 'average citizen'}

Having established the idea that we are in a debate, and that it is a difficult debate because of the contemporary atmosphere of anti-politics, I will now explore my third theme: that there is no such thing as an average citizen. To frame this I ask a simple question of the reader: is apathy a choice? Obviously, in some senses it is, in that any rational person would be apathetic about some of the issues they are confronting - people clearly care about some issues more than others, and governments identify literally thousands of issues as open for discussion and debate. This variation in level of interest is known in the political science faternity as the 'intensity preference'.

Consequently, it should not be surprising to us that people do not express an interest in every issue that government identifies for discussion and debate. And yet, if apathy was simply a choice, then surely across the spectrum of society we wouldn't find evidence that there were some people participating to a much lesser degree than other people in the political process, because such engagement would be distributed according to intensities of preference. On other issues, conversely, those who previously had not engaged would be found to engage, even though there would be no systematic pattern to nonengagement.

Confused? I would not have made the ridiculous statement above unless I had some evidence that told me it was completely wrong and that inequalities in participation are significant. Therefore, apathy is as much constructed as it is a choice. 
Below is some data which illustrates the scale of political disengagement that British people have in their heads. It is one of the rare surveys that asks people not only what they had done, but what they might do, using a whole range of political acts there as a measurement of this correlation between deed and desire. What is particularly interesting is that when it comes to the more substantial acts like attending a political meeting, taking part in a demonstration or forming a group of like-minded people, the gap between what people have actually done and what they might think about doing is substantial. What that tells us is that there is a potential for engagement and for participation which is not yet being delivered on.

Table 2: What British citizens do and what they might do

\begin{tabular}{|l|c|c|}
\hline & \multicolumn{2}{|c|}{ Response rate } \\
\hline Activity & \% Had done & \% Would do \\
\hline Donated money & 61.6 & 74.6 \\
\hline Voted in a local government election & 51.7 & 71.5 \\
\hline Signed a petition & 41.0 & 75.1 \\
\hline Boycotted certain products & 30.5 & 57.4 \\
\hline Raised funds for an organisation & 28.6 & 53.5 \\
\hline Bought for ethical reasons & 26.9 & 47.4 \\
\hline Contacted a public official & 25.1 & 58.8 \\
\hline Worn a campaign badge & 21.1 & 17.7 \\
\hline Contacted a solicitor & 19.1 & 58.4 \\
\hline Contacted a politician & 13.3 & 53.0 \\
\hline Contacted an organisation & 11.4 & 49.6 \\
\hline Contacted the media & 8.6 & 41.9 \\
\hline Attended a political meeting & 5.1 & 25.0 \\
\hline Taken part in a demonstration & 4.4 & 32.0 \\
\hline Formed a group of like-minded people & 4.4 & 22.0 \\
\hline Taken part in a strike & 2.2 & 21.9 \\
\hline Participated in an illegal protest & 1.4 & 11.5 \\
\hline
\end{tabular}

Source: Citizen Audit of Great Britain 2000-2001. 
Table 3: Income and participation - European evidence

\begin{tabular}{|l|r|r|r|r|r|r|r|r|r|r|}
\hline & \multicolumn{7}{|c|}{ Household's total net income, all sources } \\
\hline Activity & $\begin{array}{r}\text { 1st } \\
\text { decile }\end{array}$ & $\begin{array}{r}\text { 2nd } \\
\text { decile }\end{array}$ & $\begin{array}{r}\text { 3rd } \\
\text { decile }\end{array}$ & $\begin{array}{r}\text { 4th } \\
\text { decile }\end{array}$ & $\begin{array}{r}\text { 5th } \\
\text { decile }\end{array}$ & $\begin{array}{r}\text { 6th } \\
\text { decile }\end{array}$ & $\begin{array}{r}\text { 7th } \\
\text { decile }\end{array}$ & $\begin{array}{r}\text { 8th } \\
\text { decile }\end{array}$ & $\begin{array}{r}\text { 9th } \\
\text { decile }\end{array}$ & $\begin{array}{r}\text { 10th } \\
\text { decile }\end{array}$ \\
\hline $\begin{array}{l}\text { Contacted } \\
\text { politician or } \\
\text { official }\end{array}$ & 10.8 & 11.8 & 12.7 & 12.3 & 14.8 & 15.1 & 16.5 & 18.8 & 20.1 & 23.9 \\
\hline $\begin{array}{l}\text { Worked in } \\
\text { political party }\end{array}$ & 2.2 & 2.7 & 3.0 & 2.9 & 3.4 & 3.4 & 3.8 & 4.7 & 5.4 & 5.4 \\
\hline $\begin{array}{l}\text { Worked } \\
\text { in another } \\
\text { political agency }\end{array}$ & 9.1 & 11.8 & 11.7 & 14.4 & 16.0 & 16.9 & 21.6 & 22.0 & 22.2 & 25.2 \\
\hline $\begin{array}{l}\text { Worn or } \\
\text { displayed } \\
\text { political badge }\end{array}$ & 6.0 & 5.8 & 6.5 & 7.3 & 8.4 & 9.1 & 11.8 & 12.2 & 13.5 & 13.1 \\
\hline $\begin{array}{l}\text { Signed petition, } \\
\text { last 12 months }\end{array}$ & 18.5 & 19.0 & 20.7 & 23.0 & 26.6 & 26.8 & 30.0 & 33.2 & 34.8 & 38.1 \\
\hline $\begin{array}{l}\text { Taken part in } \\
\text { lawful public } \\
\text { demonstration }\end{array}$ & 4.3 & 4.9 & 5.9 & 6.4 & 7.5 & 7.6 & 6.9 & 8.6 & 8.2 & 7.9 \\
\hline $\begin{array}{l}\text { Boycotted } \\
\text { certain } \\
\text { products }\end{array}$ & 14.2 & 14.1 & 14.1 & 15.2 & 19.8 & 23.0 & 24.3 & 27.0 & 26.7 & 32.5 \\
\hline $\begin{array}{l}\text { Member of } \\
\text { political party }\end{array}$ & 3.2 & 4.1 & 3.2 & 4.4 & 4.7 & 4.4 & 4.8 & 4.7 & 5.9 & 5.6 \\
\hline
\end{tabular}

Source: European Social Survey, 2006-08.

The evidence on inequality comes from the European Social Survey and draws upon 24 countries, running their income levels against various forms of political activity. It is not necessary to study the data in detail to see evidence of the trend: lower income levels equate with lower levels of participation, whereas higher income levels lead to higher levels of participation. It's a strong pattern, and there's no doubt that it's an important one too.

Table 4 offers another approach to this subject, using UK data for the Hansard Society. Grades A and B denote the professional and managerial classes, grades $\mathrm{D}$ and $\mathrm{E}$ the working classes. Obviously differences exist between these groups across a whole series of measures. These differences are in many ways more pronounced than those between men and women or between majority and minority communities. There are significant differences regarding the level of activism; for example, if you're an A or B kind of person, you're five times more likely to be counted as a political activist, compared to a D or E person. 
Putting Citizens First

Table 4: Social factors and participation, United Kingdom

\begin{tabular}{|l|l|l|l|l|l|l|}
\hline $\begin{array}{l}\text { Political factor } \\
\% \text { of }\end{array}$ & $\begin{array}{l}\text { Social } \\
\text { grade } \\
\text { AB }\end{array}$ & $\begin{array}{l}\text { Social } \\
\text { grade } \\
\text { DE }\end{array}$ & Men & Women & White & $\begin{array}{l}\text { BME } \\
\text { (black and } \\
\text { minority } \\
\text { ethnic) }\end{array}$ \\
\hline Interest & 77 & 36 & 63 & 53 & 60 & 41 \\
\hline Knowledge & 73 & 29 & 63 & 43 & 54 & 39 \\
\hline Activist & 25 & 5 & 12 & 15 & 14 & 5 \\
\hline Voting & 72 & 43 & 57 & 59 & 60 & 44 \\
\hline Efficacy & 31 & 30 & 31 & 29 & 29 & 38 \\
\hline
\end{tabular}

Source: Developed from data in the Hansard Society Audit of Political Engagement, 2011. Ipsos MORI.

There are also some other interesting distinctions. Take the finding that men have 63 per cent knowledge of politics, compared to women at 43 per cent of knowledge. As the more detailed work went on to prove, however, this was simply because men were more boastful about the knowledge that they had (again, not a major insight).

\section{Some new insights into citizen engagement with the political process}

Some fascinating work about how different personality types might be inclined to engage with politics in different ways has also been conducted. There is also interesting work being done on the role of emotion, particularly anger, in driving people's participation in and engagement with the political process. Again, this is a significant issue if you try and frame participation as some kind of managerial solution, especially if it turns out that people have to get angry before they engage. And, finally, we also know that friendship networks and networks of people who are acquainted with politics play a significant role in driving political engagement and encouraging people who may otherwise be apathetic about politics to show interest in a particular political issue.

Another issue that deserves further research is what exactly are the problems citizens' have with politics and the representative process. Current attempts to determine this involve focus groups exploring what people find problematic or alienating about politics and why they find engagement with it difficult.

While the above research will help in our understanding of public participation in the political process, the standard starting point remains recognition that socioeconomic variables influence inequalities of political engagement. 
Systems need to cope with diversity; some research has been conducted on how to engage with hard-to-reach groups and how to ensure that they are involved in the political process. More generally, when considering systems of engagement, those that are direct, straightforward and simple tend to display less bias. In other words, the differential between somebody being asked to vote, as opposed to somebody who spends a huge amount of time on deliberating about it, is one where voting would tend to show less inequality and less difference. As we already know, different forms of non-partisan engagement are attractive to people who won't engage in mainstream politics. Thus, creating different opportunities for people to engage seems to be the most obvious way to address issues of inequality.

An audit tool to enable public authorities to consider methods and levels of participation among stakeholders has been developed by myself, in collaboration with Lawrence Pratchett and Vivien Lowndes. A framework, which was produced to support this tool and influenced by the CLEAR framework (see Table 5), is being used extensively in Europe and some parts of Australia.

Table 5: CLEAR - an audit framework

\begin{tabular}{|l|l|l|}
\hline Factor & Audit check & Policy response \\
\hline Can do & $\begin{array}{l}\text { The resources that people have as } \\
\text { well as confidence to use them }\end{array}$ & $\begin{array}{l}\text { Capacity building aimed at } \\
\text { individuals or communities }\end{array}$ \\
\hline Like to & $\begin{array}{l}\text { A sense of involvement with the } \\
\text { public entity that is the focus of } \\
\text { engagement }\end{array}$ & $\begin{array}{l}\text { Sense of community, civic } \\
\text { engagement, social capital and } \\
\text { citizenship }\end{array}$ \\
\hline Enabled to & $\begin{array}{l}\text { The civic infrastructure of } \\
\text { organisations that organise } \\
\text { participation. }\end{array}$ & $\begin{array}{l}\text { To support the civic infrastructure: } \\
\text { a set of viable civic institutions. }\end{array}$ \\
\hline Asked to & $\begin{array}{l}\text { Mobilising people into participation } \\
\text { by asking for their input can make a } \\
\text { big difference }\end{array}$ & $\begin{array}{l}\text { Public participation schemes that are } \\
\text { diverse and reflexive }\end{array}$ \\
\hline Responded to & $\begin{array}{l}\text { Participate if they are listened to } \\
\text { and able to see a response }\end{array}$ & $\begin{array}{l}\text { A public policy system that can } \\
\text { show a capacity to respond }\end{array}$ \\
\hline
\end{tabular}

Source: V. Lowndes, L. Pratchett and G. Stoker 'Diagnosing and Remedying the Failings of Official Participation Schemes: The CLEAR framework', Social Policy \& Society, v. 5:2, pp. 1-11, 2006.

The CLEAR features are likely to be familiar to the reader: the 'Can do' feature relates strongly to the socioeconomic features; 'like to' signifies that people have to feel they're part of a community that is entitled to be asked; 'enable to' and 'ask to' reflect the sense in which people are mobilised and the way that they are approached; and, finally and crucially, if we are going to make participation work, people have to be responded to (the ' $r$ ' in CLEAR). This system is useful for testing who is engaged, who isn't engaged and what the factors are that drive disengagement or engagement in certain stakeholders or communities. 
Along with other colleagues, I also have a new piece of work that frames interventions under the broad headings 'nudge' and 'think'. The 'nudge' component reflects how individuals can be approached, framing information in social cues, so as to help them do things for themselves in society. 'Think', on the other hand, captures another tradition of approaching citizens through more deliberative and collective forms of engagement. We think that a combination of 'nudge' and 'think' could make a real difference, in terms of encouraging engagement.

Obviously, the idea of 'nudge' and 'think' were created to facilitate another naff title; the book Nudge, Nudge, Think, Think was published by Bloomsbury in September 2011 and authored by myself, Peter John, Sarah Cotterill, Alice Moseley, Liz Richardson, Graham Smith and Corinne Wales.

In this book we tested the 'nudge' and 'think' interventions using randomised controlled trials. The 'nudge' approach is based on insights from behavioural science, particularly from behavioural psychology, about how it is that people approach decision-making in an irrational (or not fully rational) manner, but they are informed by cognitive and social cues in order to enable them to make decisions.

The approach then assumes that people are relatively smart decision-makers; that they can shift their behavior according to the way in which information and social messages are conveyed to them. For example, if you give them rapid feedback, or give them social information about what others are doing, or you encourage them to make a pledge, you can change their behaviour. A series of interventions tested this philosophy and it was evident that nudges work; so there is definitely something in 'nudge' and definitely something in the insights that come from behavioural science in terms of approaching people differently and giving consideration to their processes of decision-making. This leads to better outcomes. There are normative challenges involved in 'nudge' because this intervention involves an element of trickery in that the individual is being persuaded to do something without being fully informed of the context in which they do it. Even so, I think that the evidence suggests it can be decisive in changing peoples' minds.

Most of our nudges worked in a modest, rather than transformative, way. For example, during our research we created nudges that encouraged people to recycle more; as a consequence, recycling rates increased by five to seven per cent. We also designed a nudge that encourage people to volunteer more. We did this by persuading a particular local authority, when faced with a phone complaint, to reply (after addressing the complaint) in the manner of 'You sound like a person that knows quite a bit about your community. Would you like to volunteer to help out within your community?' Though the local authorities 
took some persuasion to do that (because they thought people would slam down the phone in response), eight out of 10 complainers said yes, they would like to volunteer. Indeed, a problem arose from having such a positive response because the local authority didn't have enough things for people to volunteer to do.

We have nudged people into signing up to organ donation lists and into voting, and our research indicates that there is a whole series of different ways in which you can persuade people to take a more significant civic responsibility, even if the shift is modest rather than transformative. In this sense we are looking at modest shifts; say from 20 per cent doing something to 70 per cent doing it.

Much of our evidence suggests that both nudge and think tend to work best when driven locally, rather than from a top-down perspective. The reason why nudge works more effectively on a local level is that it can only succeed if you trust the source of the nudge. And as research shows, people are more likely to trust institutions close to their community, so it makes sense they are more likely to be nudged on a local level.

The issue of whether people participate and engage at a local rather than a national level is more complicated. A narrow focus on neighbourhoods and communities misunderstands the way that citizens currently define locality. If you think about the lives most citizens lead, the notion of locality is now much more diverse and expansive than it was 20 or 30 years ago. Consider factors like the journey to work, shopping and leisure opportunities - the facilities to which individuals have access. Though they are 'local' in the contemporary context, they are potentially spread over a much wider area than they used to be. And, of course, there is the Internet, which creates communities of interest as opposed to communities of place.

We must, therefore, recognise the need to penetrate these felt communities while being careful not to assume they are always based on a street, or a neighbourhood, or a residence. In other words, we need to take locality seriously, but not narrowly define it around a small residential community.

There is an online resource devoted to this subject, currently under construction. Graham Smith is involved with people from a range of universities in making a website called Participedia Net - a kind of Wikipedia for those interested in participation. It will be invaluable for gathering people's knowledge and information and participation initiatives. It will also allow people to contribute their own findings on the topic and host relevant discussions. 
This leads to my final point about new forms of engagement: there seems to be no answer without the Internet, which has the capacity for rapid mobilisation and influence. It is clearly part of the way in which citizens are doing things and its attraction is that it lowers barriers to engagement.

I do, however, have some cautionary remarks to make about the Internet. It can be divisive and there are issues preventing its effective use as a deliberative forum. For example, one of our experiments involved an online component, for which we received substantial participation. Over 6000 people engaged in an online discussion about how to deal with anti-social behavior and 25 per cent of the participants made a significant contribution to the discussion and debate. While there was notable participation, it was evident that people entered discussions and debates in which they agreed with content posted by others; individuals sought to reinforce their opinions by accessing sympathetic online content.

\section{Concluding thoughts}

I have two concluding thoughts. The first is that in the area of citizen engagement, it is important to recognise that systems have been dominated by professionals and experts and this creates the problem of unaccountable bureaucrats. You could then say, 'well, let citizens decide,' but that potentially leads to the tyranny of the majority. Or, you could say, 'we should have specialised lobby groups and producers deciding', but that leads to the problem of self-interested particularism. Equally, the dominance of elected politicians deciding creates the problem of a construction of politics within the machine, an institutional setting that, in some sense, divorces politicians from the rest of society.

Constructing an effective and successful democracy is challenging and difficult, but it is essential to give real democracy a chance. If we take the recent example of phone-hacking undertaken by staff of Rupert Murdoch's daily UK paper News of the World, what he did was confuse popularism with democracy; he forgot that democracy involves informed engagement and participation where you take the views of others seriously. If you believe any of Murdoch's output in the United Kingdom was committed to that, then you saw it in a different way to me.

The Murdoch scandal illustrates how difficult it is to hold powerful people to account - a crucial, underpinning feature of a democracy. To achieve such accountability in a complex constitutional settlement it is necessary to have independence in the judiciary and public servants, who implement decisions and provide expertise to politicians. 
But in terms of the balancing role of citizen engagement, it is fundamental that we go much further than the current system does for one main reason: to combat the threat of fascism. Over the past 20 years Europe has seen a marked rise in right wing populist politics, a trend premised on the commonly held opinion that democracy is failing because it is not delivering any real sense of control over people's lives, and because it is allowing rich and powerful people to get away with whatever they choose, simply because they have cosy relationships with elected politicians.

The Murdoch episode brought those issues to the fore and reasserted the necessity of taking democracy seriously in order to ensure that it does not become too populist. It would be naive to imagine that people will engage all the time, however, it is important to take seriously the notion that democracy should deliver for the average citizen - the feeling that democracy works for them, rather than for other people.

We need a democracy that requires those that are powerful to take responsibility, as well as putting responsibility onto those who are less powerful. We also need a democracy that builds cohesion as well as reconciling division. The challenges, then, are significant, but they can be met if we - as public servants but also as citizens - try and encourage a much wider and much more genuine democracy. The solution is to take democracy seriously, rather than put up with the thin and rather pathetic form of democracy that has dominated in the majority of the world's liberal democracies.

\section{References}

Norris, Pippa, 2011. Democratic Deficits: Critical citizens revisited, Cambridge University Press, New York. 